\title{
Combined Oral Contraceptive Use in Young Stroke Etiology: A Case Report and Literature Review
}

\author{
Genç İnme Etiyolojisinde Kombine Oral Kontraseptif Kullanımı: Olgu Sunumu ve \\ Literatür Derlemesi
}

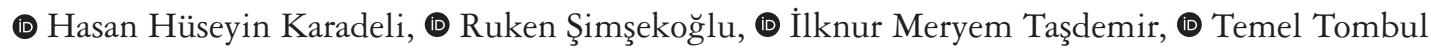
Istanbul Medeniyet University Faculty of Medicine, Department of Neurology, Istanbul, Turkey

\begin{abstract}
Oral contraceptives are associated with thromboembolic events. Thus, the use of oral contraceptive preparations must be questioned in young female patients who present with stroke. Cerebral arterial and venous thrombosis concurrently detected in a young female patient with only combined oral contraceptive (COC) use as a risk factor and acute mechanical thrombectomy treatment is reported in this case report. Treatment management and the relationship between COC use and coagulopathy will be discussed in this paper.
\end{abstract}

Keywords: Combined oral contraceptives, estrogen, young stroke

$\ddot{O} z$

Genç yaş kadınlarda inme etiyolojisi araştırılırken mutlaka sorgulanması gereken bir madde oral kontraseptif kullanımıdır. Bu olgu ile risk faktörü olarak sadece kombine oral kontraseptif (KOK) kullanımı bulunan genç yaştaki kadın hastada eş zamanlı saptanan serebral arteriyel ve venöz tromboz ile hastaya yapılan akut mekanik trombektomi raporlanmıştır. Bu hasta özelinde tedavi yönetimi ve KOK kullanımının koagülopati ile ilişkisi tartışıacaktır.

Anahtar Kelimeler: Kombine oral kontraseptifler, östrojen, genç inme

\section{Introduction}

Females are exposed to varying amounts of estrogen lifelong. Besides the menstrual cycle in reproductive age and pregnancy, combined oral contraceptive (COC), hormone replacement therapy, and fertility therapy prescriptions can also cause estrogen overload in women (1). Estrogen-containing medicines can be used for contraception and regulation of the ovulatory cycle which can be disturbed by different reasons in reproductive age. These medicines can be also prescribed in postmenopausal women to relieve symptoms of menopause or reduce the risk of elevated cardiovascular disease or osteoporosis (2).

Estrogen leads to increased levels of procoagulants such as fibrinogen, thrombin, factor 7 , and factor 8 , and decreased levels of antithrombin and the tissue pathway inhibitor (1). Furthermore, activated protein C-resistance (APC-R) is encountered frequently in women using COC. This effect can be explained by simultaneous elevation in concentrations of plasma sex hormone-binding globulin (SHBG) and plasma estrogen. Thus, in patients who take COC preparations, plasma estrogen levels, and therefore SHBG levels increase, and APC-R becomes evident (3).

The risk of thrombosis created by COCs varies according to the amount of estrogen they contain and the generation of progesterone (2). COCs are related to deep vein thrombosis (DVT) and pulmonary embolism (PE), but it is also shown that COC using can also cause upper extremity, intraabdominal or cerebral venous thrombosis (4). Arterial thrombosis is observed relatively less frequently (5). In the literature, there are rare cases of young patients with arterial and venous thrombosis with no other risk factors except the history of COC use (6).

In this report, we aimed to present a case of a young female patient who presented with cerebral sinus venous thrombosis and intracerebral major arterial occlusion who only had a medical

Address for Correspondence/Yazışma Adresi: Hasan Hüseyin Karadeli MD, Istanbul Medeniyet University Faculty of Medicine, Department of Neurology, Istanbul, Turkey

Phone: +90 5324436748 E-mail: hhkaradeli@yahoo.com ORCID: orcid.org/0000-0002-0470-8247

Received/Geliş Tarihi: 20.07.2020 Accepted/Kabul Tarihi: 27.12.2020

${ }^{\circ}$ Copyright 2021 by Turkish Neurological Society

Turkish Journal of Neurology published by Galenos Publishing House. 
history of COC use (30 $\mu \mathrm{g}$ ethinylestradiol and $3 \mathrm{mg}$ drospirenone).

\section{Case Report}

A 21-year-old woman with right-hand dominance was admitted to the emergency department with sudden-onset weakness on the left side. She had no history of chronic disease. The only stroke risk factor detected was 1.5 years of COC use. She had no medications and no known allergies.

Patient's systemic examination was normal. Her neurologic examination revealed dysarthric speech, semi-ptosis in the left eyelid, a tendency to look towards the right in both eyes, and left central facial asymmetry. The muscle strengths of the left upper and lower extremities were $1 / 5$, and she was neglecting her left side. Plantar reflex response on the left side was extensor. The National Institutes of Health Stroke Scale (NIHSS) score of the patient was calculated as 12 . There was no acute hemorrhage in her cranial computed tomography (CT), but a transverse sinus thrombosis in the right occipital was detected (Figure 1A). In diffusion magnetic resonance (MR) imaging, there was an acute diffusion restriction in the area extending from the right external capsule to the putamen, caudate nucleus, and lateral ventricle (Figure 1B). She received intravascular tPA treatment. A CTangio scan showed a right middle cerebral artery (MCA) occlusion (Figure 1C). Mechanical thrombectomy was performed and the right MCA was recanalized using a stent retriever (Figure 1D).

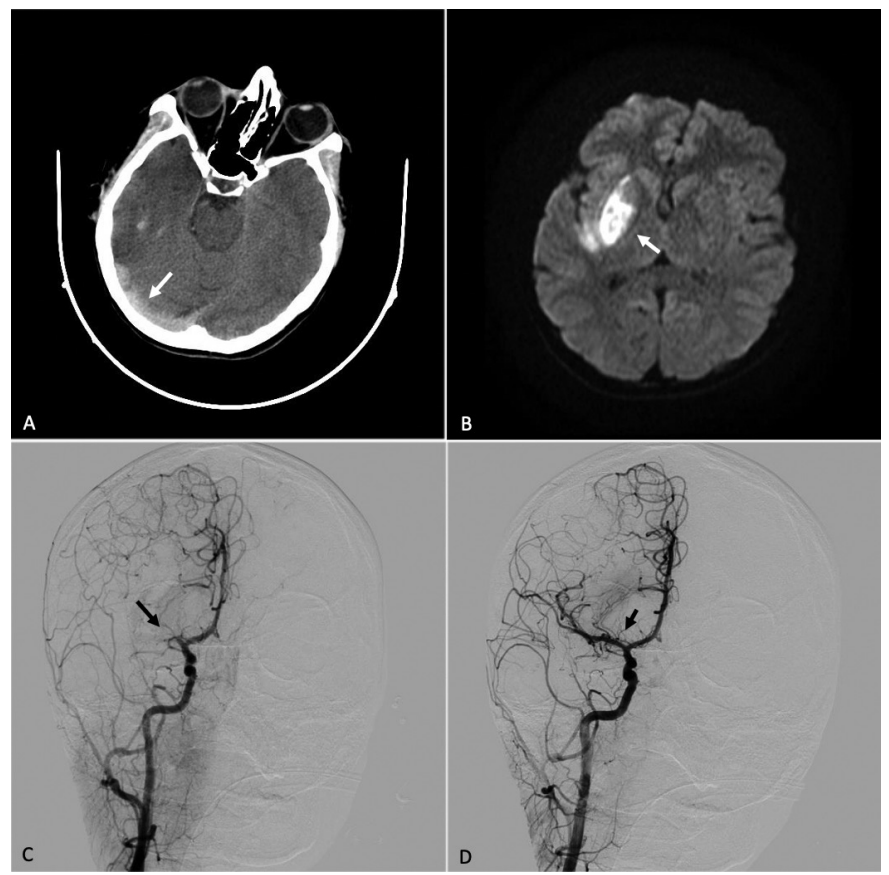

Figure 1. A, B, C, D) Radiologic images of the patient who presented with stroke. To investigate the underlying etiology of the case, a transthoracic and transesophageal echocardiogram and rhythm Holter were performed. The patient's lipid profile, levels of lupus anticoagulant, anticardiolipin antibody, antinuclear antibody, antithrombin 3, protein $\mathrm{C}$, protein $\mathrm{S}$, homocysteine were evaluated. The patient also examined for prothrombin gene mutation and factor 5 Leiden mutation. The exact etiologic cause could not be reached. Combined oral contraceptive treatment was discontinued, and $100 \mathrm{mg}$ acetylsalicylic acid treatment added
AT the $24^{\text {th }}$-hour follow-up examination, the left nasolabial sulcus was slightly subtle and there was a pronator drift in her left upper extremity. Her recalculated NIHSS score was 2.

The postoperative course was uncomplicated and she was discharged on day 10. In her follow-up, the modified Rankin Scale (mRS) of the first month was calculated as 1, and the mRS of the third month was calculated as 0 . The right transverse sinus thrombosis observed in the MR venography of the patient was seen to be recanalized in the follow-up one year later (Figure 2).

\section{Discussion}

Although the incidence of stroke is lower in women than in men for most of their lifetime, it tends to have worse results in women in terms of quality of life, depression and disability. For women of child-bearing age, the incidence of stroke is 11 per 100,000 but during pregnancy, this risk may increase to 34 per 100,000 due to estrogen in the body (7). Estrogen-containing medicines also increase the risk of stroke with a similar mechanism $(6,7)$.

COC use is one of the most important risk factors of ischemic stroke and cerebral vein thrombosis in young female patients $(1,2)$. Synthetic estrogen in COCs is accused of increasing procoagulant factors and APC-R, and decreasing tissue pathway inhibitor levels. Second-generation progesterone levonorgestrel has been shown to be the safest progesterone (8).

The main reasons for thrombosis formation in COC use are drug use over the age of 35 years, smoking, hypertension, hyperlipidemia, diabetes mellitus, previous ischemic diseases, and migraine with aura (9). Therefore, COCs are contraindicated in patients with migraine with aura (10).

Synthetic estrogen and progesterone-containing COCs can be divided into two groups regarding their estrogen levels as pills containing over and below $50 \mu \mathrm{g}$. Also, COCs can be entitled as firstgeneration (norethynodrel), second-generation (levonorgestrel) and third-generation (gestodene, desogestrel), according to their progesterone contents (9). Cyproterone acetate with antiandrogen effect and drospirenone with anti-mineralocorticoid potency is known as fourth-generation progesterone (2).

It is reported that with the use of COC, the risk of venous thromboembolism increases two-fold and the risk of arterial thrombosis increases three-fold (6). Although DVT and PE are more frequently reported related to COCs, it has been shown that COC use can also cause upper extremity, intraabdominal or cerebral sinus thrombosis (4). In research investigating data of

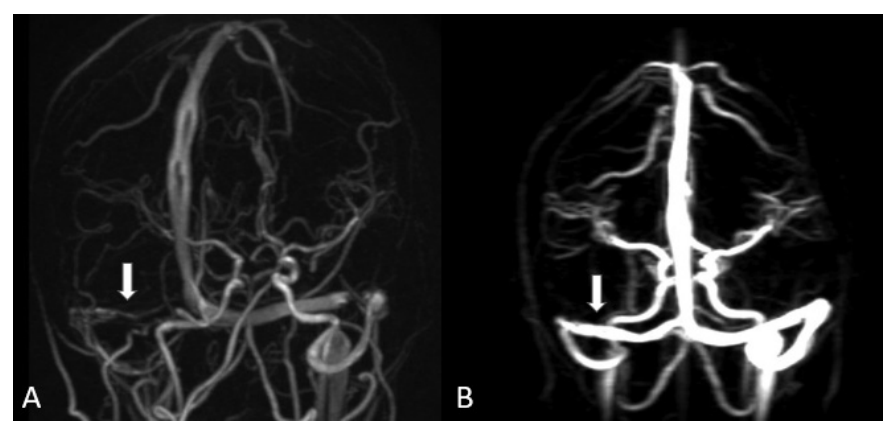

Figure 2. A, B) Magnetic resonance venography of the patient at presentation and one year later 
24 meta-analyses, it is shown that arterial thrombosis risk does not significantly increase with COC use, but the existing risk is related to the concentrations of estrogen in COCs (6). To reduce the risk of both arterial and venous thrombosis, it is recommended to prefer preparations containing second-generation progesterone and estrogen levels below $30 \mu \mathrm{g}$. Also, it is stated that smoking increases the risk of COC-related thrombosis (9). In a cohort study with five million French women, it was reported that COC preparations containing $20 \mathrm{mg}$ estrogen created a lower risk of stroke, PE, and myocardial infarction than those containing 30-40 mg (11).

Studies with progestin-only pills (POPs) showed that these preparations did not significantly increase the tendency to thrombosis. However, POPs have less contraceptive potency and are tolerated less by patients. Thus, the use of these preparations is limited (12). Hormonal contraceptive methods such as weekly transdermal patches, monthly progesterone injections, vaginal rings, and progesterone-releasing intrauterine devices should be considered in patients with additional risk factors $(9,13)$.

There are studies showing that the duration of COC usage may also affect stroke risk. As a result of the meta-analysis of six cohorts and 12 case-controlled studies published by Li et al. (14) in 2019, it was concluded that the risk of ischemic stroke would increase with the prolongation of the use of COC.

As a result, the adverse effect profile of estrogen can vary depending on the application method, daily dosage, chemical structure, and the class of progesterone preparations with which they are combined.

Patients with a history of COC use should be examined carefully when they are admitted with neurologic symptoms. COCs containing levonorgestrel and below $30 \mu \mathrm{g}$ oestrogen are safer for venous and arterial thrombosis. On the other hand, the risk of thrombosis should always be kept in mind when starting COCs, and the current comorbidities of the patient should be taken into account when starting these drugs. In patients with additional risk factors, POPs should be considered as the firstline treatment. If a patient has a thrombotic incident while using COC, the contraception method should be changed without investigating further risk factors.

\section{Ethics}

Informed Consent: A consent form was completed by the patient.

Peer-review: Externally peer-reviewed.

\section{Authorship Contributions}

Surgical and Medical Practices: H.H.K., Concept: H.H.K., T.T., Design: H.H.K., T.T., Data Collection or Processing: R.Ş.,
Analysis or Interpretation: T.T., Literature Search: R.Ş., İM.T., Writing: R.Ş.

Conflict of Interest: No conflict of interest was declared by the authors.

Financial Disclosure: The authors declared that this study received no financial support.

\section{References}

1. Carlton C, Banks M, Sundararajan S. Oral contraceptives and ischemic stroke risk. Stroke 2018;49:157-159.

2. Gialeraki A, Valsami S, Pittaras T. et al. Oral Contraceptives and HRT Risk of Thrombosis. Clin Appl Thromb Hemost 2017;24:217-225.

3. Stegeman BH, de Bastos M, Rosendaal FR, et al. Different combined oral contraceptives and the risk of venous thrombosis: systematic review and network meta-analysis. BMJ 2013;347:f5298.

4. de Bastos M, Stegeman BH, Rosendaal FR, et al. Combined oral contraceptives: venous thrombosis. Cochrane Database Syst Rev 2014;3:CD010813.

5. Chang B, Wira C, Miller J, et al. Neurology concept: young women and ischemic stroke- evaluation and management in the emergency department. Acad Emerg Med 2018;1:54-64.

6. Lowe GDO. Common risk factors for both arterial and venous thrombosis. Br J Haematol 2008;140:488-495.

7. Bushnell CD. Stroke in women: risk and prevention throughout the lifespan.. Neurol Clin 2008;26:1161-1176, xi.

8. Roach RE, Helmerhorst FM, Lijfering WM, et al. Combined oral contraceptives: the risk of myocar- dial infarction and ischemic stroke. Cochrane Database Syst Rev 2015;8:CD011054.

9. Bousser MG, Conard J, Kittner S, et al. Recommendations on the risk of ischaemic stroke associated with use of combined oral contraceptives and hormone replacement therapy in women with migraine. The International Headache Society Task Force on combined oral contraceptives \& hormone replacement therapy. Cephalalgia 2000;20:155-156.

10. Allen R, Kaunitz A, Bartz D. Use of Hormonal Contraception in Women With Coexisting Medical Conditions. Obstet Gynecol 2019;2:128-150.

11. Weill A, Marie Dalichampt M, Fanny Raguideau F, et al. Low dose oestrogen combined oral contraception and risk of pulmonary embolism, stroke, and myocardial infarction in five million French women: cohort study. BMJ 2016;353:i2002.

12. Hannaford P, Iversen L, Macfarlane T, et al. Mortality among contraceptive pill users: cohort evidence from Royal College of General Practitioners' Oral Contraception Study. BMJ 2010;340:c927.

13. WHO Guidelines approved by the Guidelines Review Committee, 5th edition. Geneva: World Health Organization; 2015.

14. Li F, Zhu L, Zhang J, He H, et al. Oral contraceptive use and increased risk of stroke: a dose-response meta-analysis of observational studies. Front Neurol 2019;10:993. 